\title{
The effects of ketogenic dieting on skeletal muscle and fat mass
}

\author{
Jacob T Rauch', Jeremy E Silva', Ryan P Lowery', Sean A McCleary' ${ }^{1}$, Kevin A Shields ${ }^{1}$, Jacob A Ormes ${ }^{1}$, \\ Matthew H Sharp', Steven I Weiner ${ }^{1}$, John I Georges, ${ }^{1}$, Jeff S Volek ${ }^{2}$, Dominic P D'agostino ${ }^{3}$, Jacob M Wilson ${ }^{1 *}$ \\ From The Eleventh International Society of Sports Nutrition (ISSN) Conference and Expo \\ Clearwater Beach, FL, USA. 20-21 June 2014
}

\section{Background}

Very low carbohydrate $(<5 \%)$, high fat $(>70 \%)$ ketogenic diets (VLCKD) diets have previously been shown to have favorable changes in body composition (increased lean mass and decreased fat mass) in obese or overweight individuals. However, the impact of this form of dieting relative to a traditional high carbohydrate diet has not yet been investigated in resistance trained athletes. PURPOSE: Therefore the purpose of this study was to investigate the impact of VLCKD verses a traditional western diet on changes in muscle and fat mass.

\section{Methods}

Twenty-six college aged resistance trained men volunteered to participate in this study and were divided into VLCKD (5 \% CHO, 75 \% Fat, $20 \%$ Pro) or a traditional western diet (55\% CHO, $25 \%$ fat, $20 \%$ pro). All subjects participated in a periodized resistance-training program three times per week. Body fat and lean mass were determined via dual xray absorptiometry (DXA), while muscle mass was determined via ultrasonography analysis of the quadriceps. All measures were taken at week 0 and 11 . Consent to publish the results was obtained from all participants.

\section{Results}

Lean body mass increased to a greater extent in the VLCKD $(4.3 \pm 1.7 \mathrm{kgs})$ as compared to the traditional group $(2.2 \mathrm{~kg} \pm 1.7)$. Ultrasound determined muscle mass increased to a greater extent in the VLCKD group $(0.4 \pm 0.25 \mathrm{~cm})$ as compared to the traditional western group $(0.19 \pm 0.26 \mathrm{~cm})$. Finally fat mass decreased to a

* Correspondence: jmwilson@ut.edu

${ }^{1}$ The University of Tampa, Tampa, Florida, USA

Full list of author information is available at the end of the article greater extent in the VLCKD group $(-2.2 \mathrm{~kg} \pm 1.2 \mathrm{~kg})$ as compared to the $(-1.5 \pm 1.6 \mathrm{~kg})$.

\section{Conclusions}

These results indicate that VLCKD may have more favorable changes in LBM, muscle mass, and body fatness as compared to a traditional western diet in resistance trained males.

\section{Authors' details}

'The University of Tampa, Tampa, Florida, USA. ${ }^{2}$ The Ohio State University, Columbus, Ohio, USA. ${ }^{3}$ University of South Florida, Tampa, Florida, USA.

Published: 1 December 2014

doi:10.1186/1550-2783-11-S1-P40

Cite this article as: Rauch et al:: The effects of ketogenic dieting on

skeletal muscle and fat mass. Journal of the International Society of Sports Nutrition 2014 11(Suppl 1):P40.

Submit your next manuscript to BioMed Central and take full advantage of:

- Convenient online submission

- Thorough peer review

- No space constraints or color figure charges

- Immediate publication on acceptance

- Inclusion in PubMed, CAS, Scopus and Google Scholar

- Research which is freely available for redistribution 